\title{
Preface: Reflections on the Georgian State
}

[Based on a public lecture given at Ivane Javakhishvili Tbilisi State University, 12 February 2015]

I must confess I have never been quite so anxious as I am today, despite my long experience speaking in public. The reason for this is because of where I am now: Tbilisi State University. Our meeting today is the continuation of a tradition inaugurated by Ivane Javakhishvili, ${ }^{1}$ a founder of this university, when he delivered the first annual public lecture within these very walls on 12 February 1918 . Of course, this is a great honour for me, and a huge responsibility.

I selected as the topic "our state." Why "our state"? I was moved by two principal reasons. First, we are at the university named after Ivane Javakhishvili. The topic I am addressing was the focus of Ivane Javakhishvili's own studies. His dissertation "dzveli sakartvelos da dzveli somkhetis sakhelmtsipo tsqobileba" (The state structure of ancient Georgia and Armenia), written between 1905 and 1907, focused on state organization in ancient Georgia. His first public lecture in the newly founded Tbilisi University in 1918 was devoted to the role and place of the personality in the history of Georgia. His fundamental work kartuli samartlis istoria (The history of the Georgian justice system), published between 1919 and 1928, is of indispensable value to all Georgian lawyers as well as historians, and concerns the development of legal systems in Georgia. Javakhishvili was one of the very first students of the Georgian state and statehood. He did much to enlighten our present generation about the nature of the Georgian state and the traditions upon which it was founded. Javakhishvili goes back to our origin as a nation and as a state.

The second reason I speak of "our state" is connected to the issue of "contemporaneity." In the historical development of the Georgian nation, the most important and fundamental challenge has always been 
how to create and establish a state in the world political system. We still face this problem in the twenty-first century. This is our task today, and we are fortunate to have the opportunity. But we are less fortunate in finding answers. We have not finished creating our state. This is why when we speak of "our state" we should become more conscious of what we mean by "our," and what we are claiming by the term "state." What is it that makes the state ours and makes us not so much the masters and owners, but caretakers and builders? I shall avoid a deep excursus into the issue, as Javakhishvili has already examined the origins of the Georgian state, its development, and how it responded or failed to respond to the challenges that brought us to the communist era. I will rather talk about post-Javakhishvili - that is, the post-communist period and the challenges we face today.

\section{Soviet Perceptions of the State}

Let us start with a little history. I studied law here between 1985 and 1992. The reason I was enrolled here for seven rather than five years was not because I was a lazy student but because I served two years' military service in Ukraine between 1986 and 1988 (students like me were drafted by the Soviet Army for its infamous military adventure in Afghanistan). What I left in Georgia when I was conscripted in 1986, and what I found when I returned in 1988, were two very different things. Between 1985 and 1986, freshmen in the law department were taught Vladimir Lenin, works such as his State and Revolution and so on. ${ }^{2}$ The chief tenet of these works was a belief in the imminent death of the state and its ultimate abolition. Communist ideology argued that, when humans reached an advanced phase of development, states would no longer be necessary. The state was a vile product of the bourgeois system and a weapon in the battle against humanity; it was a useless mechanism that would inevitably perish, abolished by history.

Imagine the thoughts of Georgian students, having entered this institution in order to study law and become specialists of statehood and jurisprudence, when they were told that all one had to do was wait a little longer, at which point neither the state nor law would be necessary. These ideas would be replaced by communist morality; there would be no need for laws and lawmakers. After I returned from the Soviet Army in 1988, perestroika was already in action, and to a certain degree, we, as students, were allowed to think freely and to learn bourgeois theories that had hitherto been mentioned only critically in textbooks and footnotes. The concepts of a "lawful state" and "the rule of law" made their appearance, and our professors were able to tell us what we had 
apparently always anticipated. This small breeze of freedom meant that theories and new conceptions could find some reflection in our real life. The creation of an independent state, sovereignty, the foundation of a legal state system, human rights, and private property, were now something that belonged to us too.

The reason I recall this is because I was not the only one "stamped" by Leninist ideology, a belief system which dominated my world as a student, as well as the world of my friends, family, and colleagues. This same ideology was "stamped" - and the stamp is still visible - onto our society. We were taught these ideas at university; others encountered them in public and social life. I want to highlight this as a very important problem today - we still encounter distorted understandings of statehood, and most alarmingly, we encounter them not only in my generation, or in older generations, but also among our youth.

\section{The Attitude of Citizens towards the State}

We have serious issues in the sphere of statehood precisely because of our teaching and educational deficits. Without a proper understanding of statehood, our reality will never reflect our ideas and aspirations. We need to understand the functions of the state just like we understand a glass of water - is it dirty or clean, when should we drink it, and when should we not? This is a very serious problem in Georgia today. It cannot be tackled by schools and universities alone if other socially influential forces - political institutions and societal organizations that shape our social life and political consciousness - do not deal with these matters critically.

What, then, must we comprehend? First, how do we become a "we"? When we speak of "our state," who is the "we" here? Who is included in the category of "we"? The right, the left, the Zviadists, the Mishistis, the Otsnebists? ${ }^{3}$ Professors? Students? Those from Eastern Georgia, or from mountainous Georgia? Religious minorities? Or just the majority perhaps? As soon as we begin to see ourselves through such categories and think of the state only after such considerations, we are committing a great mistake. If "we," in relation to our state, are not a union of citizens, and are instead united first and foremost to "our faction" of whatever kind (political, regional, or even professional), then "our" attempt to build a state turns into an internal struggle between "us" and "them" - a process that undermines the state, and creates what I call a Cold Civil War.

Cold War is not only a category of international conflicts and proxy wars. It can be systems at conflict with one another internally. The Cold 
Civil War I refer to is one of constant enmity, and it shall last in our country until citizenship has become our primary consciousness - that we, by virtue of being citizens, are equals and that this state belongs equally to all of us. We all have to demand a state that treats us equally as citizens. If we have a society in which we focus on the differences, seek out "the other," conspire to bring those who are different down, yearn to prove their fatal mistakes, this is the Cold Civil War that destroys a fragile social system like ours. ${ }^{4}$ It literally eats away at the tissue that holds society together. We cannot then mould a state that we can call "our state." And when we, the citizens, cannot unite around "our state," then the state that we want will fall into the hands of someone else, be it one man, one party, or the proponent of the one and only ideology. In such cases, we will not be state building, but someone will be seizing the state. The alienation between citizen and state automatically follows.

This brings us back to a communist understanding of the state, which we considered unacceptable because it was in the hands of others. And in the hands of others, the state was perceived as a weapon aimed against me, against us. And though I may be with my state, I have no relationship towards my state, one that I can call mine and that exists for me. Herein lies the problem of alienation that undermines important stages in the development of a democratic society. Why is it that we have for twentyfive years been in a state of almost unceasing Cold Civil War? How can we end a societal life that is founded upon, and organized around, enmity?

The difference between enmity and competition is something our post-communist consciousness does not comprehend. Competition results not only in my own advancement, but in the advancement of others. Yet, if my energies are devoted to harming those who are better than me, if I fight by any means to eliminate them from contention, I destroy those who are better than me. Quality will be lower so I can remain where I am. Competition is when I try to be better than someone else; this is what drives society forward. Instead, we continue to preserve internal enmity and suppress opposing viewpoints.

To say whatever the other does is wrong or is of no use, that he only makes mistakes, or that he must be fired, or should be punished, or that my competitor, who threatens my position, must be neutralized - this is not profitable for any healthy society or individual citizen. Competition, by contrast, is! A healthy society is based upon conflicting parties united by ideas of common citizenship and competition. Attempts at homogeneity based on ideology - the claim that we should all be left wing, pro-NATO, or Orthodox - are comparable to everyone claiming we should all become artists, musicians, or professors. All such attempts are destined to failure. Such things cannot happen. This is not the type 
of unity that enables us to construct a political system, which in turn enables us to be "us."

\section{Multiparty Democracy and Respecting Differences}

During my early university years, everything was simple, too simple. There was one party protected by Article 6 of the Soviet constitution; the Communist Party was the only true defender of the citizenry, and thus the only possible party that could exist. A single party with a monopoly over the truth had been elevated to a constitutional category. Society was aligned with this political system. There were some, within these walls, for whom Article 6 was empty. One of them is here today: Mr Levan Aleksidze. ${ }^{5}$ He was the vice-chancellor of the university and our great supporter. By "our," I mean a certain circle of students who were in the mood for revolt. That was especially true for law students facing the wholly unintelligible and unimaginable career of policeman or prosecutor. However, by 1992, when we were finishing our fifth year, those goals had changed completely - more than half of the students now wished to become defense lawyers. That was because, in that interval, we had become an independent state. A new Georgia was born, or was being born, and the realization was dawning on us that a lawyer's chief duty was not to serve an abstract state, but to serve particular human beings and their rights! That included serving the state, insofar as it protected human rights. A lot has happened since the first multiparty elections of 1990 - the first democratic elections in the post-communist space. This year - 2015 - marks the twenty-fifth anniversary of those elections; I can see a number of victors of that election here today. I was a member of the Central Electoral Commission at the time.

Those hitherto hardly conceivable elections became the foundation of a multiparty system in Georgia. But have we created a multiparty system, or is it more like a multi-communist-party system? Although all our parties were created as anti-communist entities, the process ended with the "best" communist tradition - namely, all of us believing that we possessed a monopoly on the truth. We are not communists today, we are different, but we each believe that the truth resides with us! And if the truth is with me, or you, then we must fight against those with false beliefs. This leads to the same issue of competition versus enmity. The reason our democratic progress is weak is because we cannot leave this legacy behind. And here I point to political parties, because it is here that the problem is most evident.

We participate in elections, but what happens next? Do we go to the elections with the idea that you should all cast votes in favour of me 
and my party so that we can rule this country? Or perhaps, more appropriately, with the idea that you are casting votes in my favour so that I can then negotiate your interests with other parties? Not because I like the leader of the other party, or because I care about its future ... No! Rather, it is because this or that party elected to parliament represents a fairly large group of my fellow citizens. So, when I talk to Mr Gubaz Sanikidze, who is in this hall, I talk to him as a colleague representing the National Forum. ${ }^{6}$ But by speaking with him, do I just speak with him? No. I am also talking to his supporters, one significant part of the citizenry of this country who like him and his policies. I believe they are wrong to support him. And his voters believe, undoubtedly, that my supporters are wrong to vote for me. So what? It is our duty to respect one another and one another's voters. That is, to respect those that are different from us. We should also realize that if we do not respect the other representatives and their voters, then neither will they respect me or my voters. Then we enter the mode of enmity. So, we - civil society, citizens - should make the state "ours" and the same as everyone else's. In so doing we create a general framework for our state's development and our future. Unfortunately, we are still stepping in the wrong direction. There are many matters we still need to change. And if this cannot be done at the level of the political system, then it will be very hard to resolve these matters in the lecture halls of our universities.

\section{On the Importance of Publicly Naming Our State's Problems}

Depending on the circumstances, public issues must be addressed by different institutions - sometimes governmental actors are better positioned and other times non-governmental actors are more effective. In 2000, I, along with a number of colleagues, commenced work on an anti-corruption program. Georgia in 2000 had almost no governmental capacity, and was a swamp of immobility and corruption. It was what we call a "failed state." The first idea that sprang to our minds was to create a new, strong executive body that would have powerful officials, agents, and instruments for enforcing the law. And with fire and sword, we would eradicate corruption. But we were soon forced to conclude that this would not solve the problem, because criminal law is interconnected with multiple social, psychological, and economic problems in society at large, which last longer than prison sentences.

If theft, bribery, domestic violence, nepotism, or even rape are not recognized in society as inherently bad, if children are not socialized into avoiding such behaviour by their parents, if a given crime is not 
condemned at the social and moral level, then no police, no prosecutors, no jails will ever solve these problems. In the Soviet Criminal Code, speculation was punishable. Today this might be wholly unimaginable for our younger generation, because "speculation" in the past did not mean inventing a lie and repeating it. It had a different meaning. If someone bought a bag of flour in Batumi, brought it to Tbilisi and sold it for 20 rubles more, this was speculation - one of the most serious crimes of the time! Yet the history of humankind teaches us that one of the most significant drivers of economic and social development is private property and the human desire to increase personal wealth, and thereby enhance the common wealth. This was prevented by the Soviet Criminal Code. What drove the capitalist economy was seen as "speculation," and was punishable by years in prison. But this article did not work, because we, Georgians and others, knew where to find anything that was prohibited. For instance, we could always find American jeans on the black market, or buy for additional rubles good champagne secretly smuggled out of the shops. Books, too, were sold by "speculators." The criminal clause against speculation never worked, so great was the difference between official values and the socially acceptable "code of behaviour."

In 2000 when we talked of our relationship to the state, corruption was the central problem. It was built into our social consciousness; no police force could deal with it. Corruption in Georgia was not just a set of isolated legal offences. In many fields, corruption had become an established lifestyle, and corrupt beliefs had penetrated the social consciousness. Thus, it was critical to separate carefully those corrupt habits that would lead to a national catastrophe from those features that constituted a genuine part of the national culture. The generally low moral climate was one of the chief reasons for the spread of corruption. While corruption on a grand scale could prompt public protest, the majority of the population endured wide-scale corruption and considered it an inevitable part of life. Moral guidelines appeared lost, and allegations of corruption did not decrease the social prestige of a person. An "everyone does it" attitude prevailed, and much of the public ascribed improper motives to those who tried to expose corrupt practices.

The issue we registered as number one in our program - we listed over 250 problems of corruption and an equal number of policy solutions in total - was the battle against corruption in the university system. We concluded that, if society could live with a professor who would accept favours, such as an invitation to a restaurant or a bottle of cognac, and who would then award high marks to a student, if this was the normal course of things at the university, the very heart of our education and our claim to being civilized, then how could we possibly tackle the same 
phenomenon in the police force? Or in the Tax Inspectorate? Or among customs officers? This was impossible. We held meetings, and were told by the university administration that "there was no corruption in the university!" "How is that?" we replied. "Has such bribery of professors not occurred?" "Oh, you mean protection? That's not corruption." In 2000, we made no progress because there was no political will. That has changed in recent years. A mental, or perhaps societal, battle against corruption has begun. Social values are changing. But the point remains. Corruption cannot be defeated in society so long as it is permissible in education and in the family!

The anti-corruption struggle must not be presented as one group of society fighting another, so when one wins another loses. The campaign against corruption has to provide a basis for national and state consolidation, rather than further disintegration. It must be viewed as an attempt by Georgian society ("us") to cure itself of corruption ("us"). Only this approach can lead to increased public trust in state institutions and stop the erosion of the moral foundations of civil society, the most dangerous process inherited from the communist past. We have achieved remarkable success in combatting petty corruption since 2004, but at the same "we" have failed to do the same with elite corruption, especially political or election-related corruption. "We" risk going back to 2000 if we do not strengthen "our state" institutions sooner rather than later.

\section{A State Founded upon a Conception of Liberty and upon the "Right to Fail"}

In the process of citizens becoming "us," the political leaders and political parties should provide the strongest leadership. If we are to become "us" and the state "ours," we must organize not around me, nor around you; neither should we expect others to think like you or to understand unity as one opinion. However noble the aims - regardless of great leadership, moral worth, patriotism, or passion - the moment one equates unity with uniting around "me," "our" state is lost. The state we build in the twenty-first century must be founded on the concept of liberty more than anything else. This presupposes one fundamental issue: our "right to make mistakes," including political mistakes. We must grant one another this right. The New Testament talks of the inevitability of mistakes, even mistakes upon which much is dependent. Even if you commit a sin, you are not going to be destroyed because of that sin, so long as you can reflect and repent. Even in a system founded upon the strictest of dogmas, where the very act of asking questions about belief is deemed to be wrong, where there is practically no room for multiple 
opinions due to a high level of dogmatism, even here the system concedes a human might commit a mistake, or a sin. And he or she must be given the opportunity to change, for such is the nature of humans. If religious and ecclesiastic life is like this, why are we today, with our welldeveloped secularism, superdogmatic in this regard?

It is wrong not to grant a person the right to a mistake. This is not to say I encourage you to make an error, especially when the price can be high, and should not go unanswered. But because you have made a mistake, I will not punish you forever; I will try to persuade you that you made a mistake. And if I do not convince you, then I must admit that I, too, am possibly mistaken! But if I do not forgive you, then I am moving towards the most dangerous thing in politics: a belief in my own infallibility. That is why I do not grant you the right to make a mistake. When I believe in my own infallibility, what happens next is clear. Instead of "our state," we get "my state." I don't have to say l'état, c'est moi, but in practice I can believe this without pronouncing it. I can mask it by speaking in the name of society, I can claim that society is asking for my solution. Yet, essentially it is what I myself believe society wants. Building that state of which we dream is not so simple: the state that we want to be proud of must function without the state's or its servant's claiming some special knowledge or right to represent the interests of society. No chairman of parliament, for example, should tell you it is in the interests of the state that you should change your seat from this one to that one. An important political position brings unique access to power, but the interests of the state and society are nothing else but the sum total of the interests of each and every one of us.

We need politicians and public servants who are able to understand conflicting interests. Let us take, for example, our law "On labor migration," which is currently being discussed in parliament. ${ }^{7}$ It is clear in the law that the concerns of those who want to arrive from foreign countries and want to work here in Georgia, are different from those who already live in Georgia and are jobless. An entrepreneur setting up a business in Georgia has a different set of goals: he wants a cheap and qualified workforce, and does not care what nationality this workforce represents. A politician and a representative of the state must be able to understand these conflicting interests, should try and balance them, one against the other. He or she should not be guided by narrow interests, such as who is stronger, or who will most likely win the next election.

\section{The Presumption of Guilt}

Conduct a survey in Georgia, and everyone will tell you that the presumption of innocence is proper and necessary. But what is our own social 
life founded upon - the presumption of innocence, or something else, maybe the presumption of guilt? Our assumptions are mixed. When we meet one another in the street, we may smile, and we may presume that this person is good, decent, will not steal, or commit a crime. We see the good side of a human, until the bad side is proven. The presumption of innocence is not just a legal category in the courtroom, it helps society cohere. But when it comes to the activities of the state, very often it is the other way around. Reigning in our midst is the presumption of guilt.

Let us take elections. Parliamentary and presidential elections should in truth be the day when we are "we." On other days, we are in different places occupied with different goals. We might be sitting at a lecture, debating in parliament, travelling abroad. But the day of the elections is the day when a nation and a society demonstrate being "us." That day decides what our country will be tomorrow, who will run it, what direction it will take, what shall be emphasized, what our financial resources shall be spent on as a priority. "Our" action makes it "our" day. But what do we do on that day? On that day, half of Georgia looks suspiciously at the other half. Are they going to stuff the ballot box? Will they engage in "carousel voting?" Will they falsify the vote count? When in a hundred years from now a new Javakhishvili publishes his studies on Georgian statehood and identity at the turn of the twenty-first century, it will be enough for him to point to our Electoral Code. There is so much written against falsifying elections that it is clear what sort of moral standards we have to deal with. Those engaged in elections wish to prove that all the others are guilty. Why are you not honest? Because you are a member of that party! If you are a member of that party, you are guilty because you will do anything for the sake of your party: lie, falsify, indulge in violence, destroy an opponent. This is our deformed perception of party politics and our parties' function. This is why we come up with such security measures at election times - biometrics, fingerprints, coloured ink, and so on. This is what preoccupies us, our sense of mutual suspicion and guilt. Of course we shall steal, of course we shall deceive one another, of course we base our decisions on personal interests, we do not care about laws or about morality. I will go to the church and pray, but when I leave the church, I will go to the electoral box and stuff it. We want European integration, we strive towards the European family, we affirm ourselves as a European civilization, a part of European culture. But how is this manifested? We have learned a little here and there, but do we really wish to organize the state in a European manner?

In Europe, they conduct election monitoring as well, but not with the belief that 99 out of 100 voters would cheat if not closely watched (as we do), but with the belief that 1 out of 100 voters could cheat, and even this 
must be prevented. Until cheating in elections is ruled out in Georgia by our collective and individual consciousness, no laws or strict oversight measures will make us Europeans.

\section{The Importance of Critical Thinking and Active Citizenship}

Are we a union of free citizens who wish to build and strengthen a state of free citizens - "our state"? Or are we simply a union of law-abiding citizens who live and work in a system of statehood over which we have little control? Obedience to the law and to freedom are both important and noteworthy ideas, but we must connect them to one another. If a citizen is only law abiding, then he or she can't be the type of citizen who is a member of "our state," who cares for the state and serves it. Obedience to the law is not enough for the connection between "we" and the state. Even more necessary is "rebellion" within the confines of the law - that is, we must have a critical relationship to those laws and rules that exist in a given state.

There must be rules that are understood by all; we all know that we should walk when it's green and stop when it's red. If this is not known by other people, a disaster is inevitable. But the citizens constituting "our state" should have the ambition, the courage, and ability to ask above all else the following question: is it, perhaps, better the other way around, to stop when it's green and walk when it's red? A citizen who never subjects norms to questions is not a fully participating citizen. The citizens of "our state," our fellow citizens, must be willing and able to ask questions in whatever field they work. If we are citizens of a state, this means that, whatever social segment we come into everyday contact with - at the shops, in the factories, in universities, parliament, and so on - we are always dealing with rules, and a rule is not generally a rule if it does not limit something. If citizens do not challenge those limits, then that limits citizenship. Parliament has now passed a law that makes punishment for domestic violence stricter. The active citizen should not applaud this simply because he or she believes that domestic violence has increased, and that greater punishment will diminish such violence. This is a simple way of thinking by the law-abiding citizen. The level of thought that our fellow citizen requires should lead to the question: wait a moment, will the doubling of punishment ensure the desirable result? If the chief problem is the lack of reporting, and if the Code previously punished the crime with one year or a fine, if the crime is now to be punished with five years, will the number of reports increase or decrease? That fellow citizen of ours who is to build and create our state must be able to see and calculate at least two or three different consequences of this law, or 
any other law. We cannot wait for the moment when things are at the edge of the precipice, and then gather by the university or march along Rustaveli Prospect ${ }^{9}$ and depose someone who has made a mistake. We are latecomers, we move from "government obedience" to revolution, and this is not a positive impulse for democratic development. Obedient citizens, law abiding or whatever abiding, they wait; but the active citizen does not wait, neither does he or she transform every protest into a Second Coming.

We should ensure active citizenship becomes normal citizenship, that our different opinions regarding rules and decisions are conveyed calmly and strategically. This means that we support the unity of citizens because we all would like to be respected, prized, and acknowledged. Thinking of the state in these terms means we must become civic-minded citizens concerned with the common good.

I want to finish with disclosing the true meaning of the magic word "us" and its connection to civil society. In a strong civil society, we shall be able to create "our state," which protects us, of which we are proud, and through which we solve social and political problems. Despite many difficulties and missed opportunities, we have made progress in this direction. We have made unimaginable progress. For these sorts of transformations, two years, ten years, twenty-five years is nothing. I am a witness. I have told you how things were in these very walls in the past. We are elsewhere today. Let us continue the process; let us hope, and let us do what citizens must do.

David Usupashvili (trans. by Grigol Gegelia)

\section{NOTES}

1 Ivane Javakhishvili (1876-1940) was a linguist and one of Georgia's greatest modern historians. Known widely for his monumental kartveli eris istoria (A history of the Georgian nation), he was one of the founders of Tbilisi University in 1918. He served as rector of the university, which now bears his name, from 1919 to 1926.

2 V.I. Lenin's State and Revolution (1917) is considered to be one of his most important works and is a merciless critique of parliamentary democracy.

3 These epithets refer, respectively, to the followers of Zviad Gamsakhurdia, president of Georgia from 1991 to 1992 (the Zviadists), to the supporters of Mikheil Saakashvili, president of Georgia from 2003 to 2013 (the Mishists), and to the followers of Bidzina Ivanishvili and his party, Georgian Dream, or kartuli otsneba (the Otsnebists). 
4 Unfortunately, during the 2018 presidential elections, Georgian society suffered yet another devastating Cold Civil War. The level of hatred demonstrated by the supporters of the current leader Bidzina Ivanishvili and former president Saakashvili further divided society into two hostile camps, which consider each other "usurpers" who have to be destroyed or expelled.

5 Levan Aleksidze (1926-2019) was a prominent jurist, professor of international law, and diplomat during the 1990s and 2000s. From 1993 to 2003, he was chief advisor to Eduard Shevardnadze, president of Georgia from 1995 to 2003.

6 The National Forum is a political party, established in 2006. Gubaz Sanikidze was one of the founders and leaders of the party before his resignation in 2017.

7 The Law on Labor Migration, effective since November 2015, regulates the norms of labour emigration of Georgian citizens abroad, as well as access to Georgia's labour market by aliens residing in Georgia on a legal basis.

8 A system of ballot stuffing, when large groups of voters are hired to visit multiple polling station and vote multiple times.

9 Rustaveli Prospect is the main thoroughfare in Tbilisi, where all major civil actions and demonstrations take place. 
This page intentionally left blank 